\title{
A phase I pharmacokinetic study of the vascular disrupting agent ombrabulin (AVE8062) and docetaxel in advanced solid tumours
}

\author{
F A L M Eskens ${ }^{*}, 1$, P Tresca ${ }^{2}$, D Tosi ${ }^{2}$, L Van Doorn ${ }^{1}$, H Fontaine ${ }^{3}$, A Van der Gaast ${ }^{1}$, C Veyrat-Follet $^{4}$, \\ C Oprea ${ }^{3}, \mathrm{M} \mathrm{Hospitel}^{5}$ and $\mathrm{V}$ Dieras $^{2}$
}

${ }^{1}$ Department of Medical Oncology, Erasmus MC Cancer Institute, PO Box 2040, 3000 CA Rotterdam, The Netherlands; ${ }^{2}$ Clinical Research Unit, Institut Curie, 26, rue d'Ulm, 75231 Paris Cedex 05, France; ${ }^{3}$ Oncology Division and Trial Operations Department, Sanofi, 13 Quai Jules Guesde, 94400 Vitry-Sur-Seine, France; ${ }^{4}$ Division of Drug Disposition DSAR, Sanofi, 1 Avenue Pierre Brossolette, 91380 Chilly-Mazarin, France and ${ }^{5}$ Division of Biostatistics \& Programming, Sanofi, 13 Quai Jules Guesde, 94400 Vitry-Sur-Seine, France

Background: The vascular disrupting agent ombrabulin shows synergy with docetaxel in vivo. Recommended phase II doses were determined in a dose escalation study in advanced solid tumours.

Methods: Ombrabulin (30-min infusion, day 1) followed by docetaxel (1-h infusion, day 2) every 3 weeks was explored. Ombrabulin was escalated from 11.5 to $42 \mathrm{mg} \mathrm{m}^{-2}$ with $75 \mathrm{mg} \mathrm{m}^{-2}$ docetaxel, then from 30 to $35 \mathrm{mg} \mathrm{m}^{-2}$ with $100 \mathrm{mg} \mathrm{m}^{-2}$ docetaxel. Recommended phase II dose cohorts were expanded.

Results: Fifty-eight patients were treated. Recommended phase II doses were $35 \mathrm{mg} \mathrm{m}^{-2}$ ombrabulin with $75 \mathrm{mg} \mathrm{m}^{-2}$ docetaxel (35/75 $\mathrm{mg} \mathrm{m}^{-2} ; 13$ patients) and $30 \mathrm{mg} \mathrm{m}^{-2}$ ombrabulin with $100 \mathrm{mg} \mathrm{m}^{-2}$ docetaxel (30/100 $\mathrm{mg} \mathrm{m}^{-2} ; 16$ patients). Dose-limiting toxicities were grade 3 fatigue (two patients; 42/75, 35/100), grade 3 neutropaenic infection (25/75), grade 3 headache (42/75), grade 4 febrile neutropaenia (30/100), and grade 3 thrombosis (35/100). Toxicities were consistent with each agent; mild nausea/ vomiting, asthaenia/fatigue, alopecia, and anaemia were common, as were neutropaenia and leukopaenia. Diarrhoea, nail disorders and neurological symptoms were frequent at $100 \mathrm{mg} \mathrm{m}^{-2}$ docetaxel. Pharmacokinetic analyses did not show any relevant drug interactions. Ten patients had partial responses (seven at $30 \mathrm{mg} \mathrm{m}^{-2}$ ombrabulin), eight lasting $>3$ months.

Conclusions: Sequential administration of ombrabulin with 75 or $100 \mathrm{mg} \mathrm{m}^{-2}$ docetaxel every 3 weeks is feasible.

Vascular disrupting agents (VDAs) exploit the often fragile structure of existing tumoural blood vessels via a variety of different mechanisms, ultimately resulting in vascular shutdown and tumour necrosis. Some VDAs cause increased vascular permeability of the arteriolar system by targeting rapidly proliferating and immature endothelial cells, resulting in their detachment from vessel walls (Hori and Saito, 2003). Ombrabulin (AVE8062, AC-7700), a microtubule-destabilising agent, is one such molecule currently under clinical investigation. This synthetic derivative of the water-soluble VDA combretastatin A4 phosphate

\footnotetext{
*Correspondence: Dr FALM Eskens; E-mail: f.eskens@erasmusmc.nl

Results were published in part at the AACR-NCI-EORTC Molecular Targets and Cancer Therapeutics Meeting, 2009 and the 46th Annual Meeting of the American Society of Clinical Oncology, 2010.
}

Received 30 October 2013; revised 6 February 2014; accepted 21 February 2014; published online 8 April 2014

(c) 2014 Cancer Research UK. All rights reserved 0007-0920/14 
(CA4P), binds at or near the colchicine site on the $\beta$-subunit of tubulin, leading to microtubule depolymerisation and cytoskeleton disorganisation (Kanthou and Tozer, 2002).

Increased anti-tumour activity is anticipated when VDAs are combined with other treatment modalities such as cytotoxic chemotherapies, anti-angiogenic agents, external-beam radiotherapy, and radioimmunotherapy (McKeage and Baguley, 2010). Encouraging results, have been observed, such as the intriguing example of the anti-VEGF antibody bevacizumab combined with CA4P (Nathan et al, 2012) or ombrabulin (Del Conte et al, 2012).

Preclinical evaluation of ombrabulin with a range of chemotherapeutic agents revealed several promising combination chemotherapy candidates. Docetaxel binds to tubulin (at a different site to that of ombrabulin) and results in microtubule stabilisation causing cell cycle arrest. Combining docetaxel with ombrabulin yielded additive and sometimes synergistic activity in a range of tumour cell lines at ombrabulin doses below the highest non-toxic dose, as was demonstrated by fractional cell kill values and antiproliferative activity on endothelial cells when ombrabulin administration preceded that of docetaxel by $24 \mathrm{~h}$ (Lejeune et al, 2005; Kim et al, 2007). This combination resulted in significant survival improvements in multiple murine tumour models, including breast and ovarian cancers, and was well tolerated. Docetaxel is widely used to treat advanced and metastatic solid tumours, in particular breast, hormone-refractory prostate, nonsmall cell lung, head and neck, gastric, and ovarian cancers, either as monotherapy or in combination with other agents.

In a phase I ombrabulin single-agent study, abdominal pain, tumour pain, and hypertension were dose-limiting and $50 \mathrm{mg} \mathrm{m}^{-2}$ was established as the recommended dose (Sessa et al, 2013). The current two-step phase I study was designed to determine the recommended phase II ombrabulin dose (RP2D) for use in combination with two standard docetaxel doses (75 and $100 \mathrm{mg} \mathrm{m}^{-2}$ ). Pharmacokinetic analyses were conducted to assess potential interactions between ombrabulin and docetaxel and antitumour activity was assessed.

\section{PATIENTS AND METHODS}

Patient selection. To be eligible, patients had to be aged 18-75 years and have a histologically or cytologically confirmed metastatic or locally advanced tumour for which docetaxel treatment was recommended. Eastern Cooperative Oncology Group (ECOG) performance status 0 or 1, adequate haematological, renal, and hepatic function, and appropriate washout since prior therapy were required. In France, women with locally advanced or metastatic breast cancer without prior adjuvant chemotherapy were excluded. Patients with grade 2 or higher peripheral neuropathy or chemotherapy-related grade 3 or higher ototoxicity according to the National Cancer Institute Common Toxicity Criteria for Adverse Events (NCI-CTCAE, version 3.0) were excluded, as were patients having received prior intensive chemotherapy with autologous stem cell rescue or a high cumulative anthracycline dose (doxorubicin $>400 \mathrm{mg} \mathrm{m}^{-2}$ or epirubicin $>750 \mathrm{mg} \mathrm{m}^{-2}$ ), patients with severe hypersensitivity to taxanes or polysorbate 80, a history of cardiac conditions, left ventricular ejection fraction (LVEF) $<50 \%$, untreated hypertension (systolic blood pressure (BP) $>140 \mathrm{~mm} \mathrm{Hg}$ or diastolic $\mathrm{BP}>90 \mathrm{~mm} \mathrm{Hg}$ ), patients receiving antihypertensive medication (other than angiotensin converting enzyme inhibitors, receptor antagonists, or diuretics), with hypertension-related organ damage, Q-wave infarction or ST segment changes $\geqslant 1 \mathrm{~mm}$ (12-lead electrocardiogram (ECG)), or ventricular tachycardia (Holter ECG). The study was approved by the ethics committees of the two participating centres (Tarnier-Cochin Hospital, France, and Erasmus MC Cancer Institute, The Netherlands) and was conducted in accordance with the Declaration of Helsinki. All patients gave written informed consent prior to enrolment. The study is registered at ClinicalTrials.gov (NCT01907685).

Study design and treatment. This phase I dose escalation study was performed between June 2006 and February 2011. Ombrabulin (Sanofi, Vitry-sur-Seine, France) was administered as a 30 -min intravenous infusion on day 1 , followed on day 2 by docetaxel (1-h infusion, $24 \mathrm{~h}$ after the end of the ombrabulin infusion), every 3 weeks. Two docetaxel doses were evaluated. Initially $75 \mathrm{mg} \mathrm{m}^{-2}$ docetaxel was investigated combined with ombrabulin at the starting dose of $11.5 \mathrm{mg} \mathrm{m}^{-2}$. This ombrabulin dose was selected based on preclinical data suggesting that a minimal dose of $6 \mathrm{mg} \mathrm{m}^{-2}$ was required for synergy with docetaxel, and from phase I single-agent weekly and intermittent regimens showing that $11.5 \mathrm{mg}$ was safe. Once the RP2D with $75 \mathrm{mg} \mathrm{m}^{-2}$ docetaxel was established, $100 \mathrm{mg} \mathrm{m}^{-2}$ docetaxel was investigated with ombrabulin at a starting dose of $30 \mathrm{mg} \mathrm{m}^{-2}$. Medications metabolised by CYP2C19 were omitted for $12 \mathrm{~h}$ prior to and after the ombrabulin infusion. LHRH agonists administered to prostate cancer patients were maintained. Growth factor treatment for therapeutic or prophylactic intent was permitted throughout the study. Antihypertensive prophylaxis was not administered.

A traditional $3+3$ design was used with initially three patients per dose level and three additional patients if dose-limiting toxicity (DLT) occurred. Occurrence of DLT during the first cycle was used to determine the RP2Ds. For each docetaxel dose, ombrabulin dose escalation was stopped when two or more patients had DLT during the first cycle, and the dose level immediately below was considered the RP2Ds and expanded with 10 additional patients.

Dose-limiting toxicity was defined as grade 4 thrombocytopaenia, grade 4 neutropaenia lasting $>5$ days, grade 4 febrile neutropaenia, grade 3 or 4 neutropaenic infection, any grade 3-4 non-haematological toxicity (other than nausea, vomiting, and hypersensitivity without adequate treatment), or any of the following cardiovascular events: documented angina pectoris, arterial thromboembolism, grade 3-4 vascular events (except tumour haemorrhage or necrosis), acute impairment of a target organ (brain, heart, kidney), troponin I or creatine kinase (CK)$\mathrm{MB}$ increase above myocardial necrosis limits, systolic $\mathrm{BP} \geqslant 180$ $\mathrm{mm} \mathrm{Hg}$ and/or diastolic BP $\geqslant 120 \mathrm{~mm} \mathrm{Hg}$ or grade $\geqslant 2$ hypotension and/or systolic BP $<90 \mathrm{~mm} \mathrm{Hg}$ (in at least two successive measurements at 30-min intervals), ST segment elevation or depression $\geqslant 1 \mathrm{~mm}$ in at least two contiguous leads or Q-wave infarction on a 12-lead ECG, severe ventricular arrhythmia or ST segment elevation or depression $\geqslant 2 \mathrm{~mm}$ lasting $\geqslant 1 \mathrm{~min}$ on a Holter ECG, or grade 2 or higher LVEF, and any other toxicity deemed dose-limiting, regardless of grade. Patients receiving at least one combined ombrabulin-docetaxel administration with clinical and laboratory examinations during the first cycle were evaluable for DLT.

Adequate laboratory values (ANC $\geqslant 1.5 \times 10^{9} / 1$, platelets $\geqslant 100 \times 109 / 1, \quad$ ALT/AST/AP $\leqslant$ grade 1 , total bilirubin within normal limits, total creatinine $<1.5 \mathrm{mg} \mathrm{dl}^{-1}$ ) and recovery from any grade 3-4 toxicity to grade 1 or baseline levels were required at the start of each cycle. A 1-week treatment delay was permitted for related toxicity. Ombrabulin treatment was stopped if a cardiovascular DLT occurred or the patient did not recover from toxicity following a 1-week delay. Ombrabulin dose reduction could be implemented following DLT or grade 2 peripheral neuropathy with recovery within 1 month or a repeat delay from the same toxicity.

Safety and tumour evaluations. Physical and neurological examinations were performed weekly. Haematology was evaluated weekly and biochemistry weekly for the first cycle and every cycle thereafter. The following exams were performed within 4 weeks prior to the first treatment administration, before each ombrabulin 
infusion, and as follows: a cardiovascular exam (6-12 and $24 \mathrm{~h}$ post-ombrabulin), a 12-lead ECG (at 6-12 h post-ombrabulin), a 24-h Holter ECG, and CK-MB and troponin I (6-12 and $24 \mathrm{~h}$ postinfusion). An echocardiography, an ocular funduscopy (in hypertensive patients) and a brain MRI were performed within 4 weeks prior to treatment start. Chest X-rays were performed prior to treatment then every 3 months. Adverse events (AEs) were evaluated according to the NCI-CTCAE version 3.0. A central review of cardiovascular toxicity was performed by an assigned cardiologist. Tumour evaluation was performed every 6 weeks and response was determined according to Response Evaluation Criteria in Solid Tumours (RECIST) version 1.0 (Therasse et al, 2000). Objective responses had to be confirmed a minimum of 4 weeks after the initial criteria were met and stable disease (SD) had to be derived from an evaluation a minimum of 5 weeks after the first dose. Duration of objective response was from first documented response until disease progression and duration of SD was from first study drug administration until disease progression.

Pharmacokinetics. The pharmacokinetics of ombrabulin and its active metabolite RPR258063 were assessed in all patients using 2 -ml blood samples collected in heparinised tubes on day 1 of cycle 1 , pre-infusion, immediately prior to the end of the 30 -min infusion, and at $5,10,25,45$, and $60 \mathrm{~min}$ then $2,4,6,8-10$, and $24 \mathrm{~h}$ post-infusion. Blood samples were collected for docetaxel analysis in heparinised tubes pre-infusion (i.e., day 2 of cycle 1), $15 \mathrm{~min}$ before the end of infusion, 15 and $45 \mathrm{~min}, 2$ and $5 \mathrm{~h}$ after the end of the infusion. Samples were assayed with a validated $\mathrm{LC} / \mathrm{MS} / \mathrm{MS}$ method using a limit of quantification of $2.0 \mathrm{ng} \mathrm{ml}^{-1}$ for ombrabulin and RPR258063 and $1.0 \mathrm{ng} \mathrm{ml}^{-1}$ for docetaxel. Non-compartmental analyses for ombrabulin and RPR258063 including $\mathrm{C}_{\max }, \mathrm{T}_{\max }, \mathrm{AUC}_{\mathrm{t}}, \mathrm{t}_{1 / 2 \mathrm{Z}}, \mathrm{CL}$, and $\mathrm{V}_{\mathrm{ss}}$ were performed using WinNonlin software, version 5.2.1 (Pharsight Inc., St Louis, MO, USA). For docetaxel, CL and AUC were determined by Bayesian estimation using NONMEM software, version $\mathrm{V}$ (Globomax, Hanover, MD, USA). A three-compartment structural model with first-order elimination was used as prior information (estimates were CL $36.81 \mathrm{~h}^{-1}, V_{\mathrm{d}}$ central compartment $7.83 \mathrm{~L}$, $V_{\text {ss }} 122 \mathrm{~L}, t_{1 / 2 \mathrm{Z}} 10.0 \mathrm{~h}$ ) (Bruno et al, 1996).

\section{RESULTS}

In total, 58 patients were treated, 39 with $75 \mathrm{mg} \mathrm{m}^{-2}$ docetaxel and 19 with $100 \mathrm{mg} \mathrm{m}^{-2}$ docetaxel. Patient and disease characteristics are summarised in Table 1 . The most common tumours were breast (36\%) and oesophageal (24\%).

Dose-limiting toxicity. Dose-limiting toxicity was evaluated in the first cycle, with 29 patients assessed at $75 \mathrm{mg} \mathrm{m}^{-2}$ docetaxel and 9 patients at $100 \mathrm{mg} \mathrm{m}^{-2}$ docetaxel. Ombrabulin was escalated from 11.5 to $42 \mathrm{mg} \mathrm{m}^{-2}$ with $75 \mathrm{mg} \mathrm{m}^{-2}$ docetaxel (Table 2). One episode of DLT was seen in a patient at $25 \mathrm{mg} \mathrm{m}^{-2}$ ombrabulin consisting of grade 3 neutropaenic infection despite receiving prophylactic G-CSF. At $42 \mathrm{mg} \mathrm{m}^{-2}$ ombrabulin, DLTs were reported in two patients, one with grade 3 headache (4 days postombrabulin) and one with grade 3 fatigue. The RP2D for $75 \mathrm{mg} \mathrm{m}^{-2}$ docetaxel was set at $35 \mathrm{mg} \mathrm{m}^{-2}$ ombrabulin $\left(35 / 75 \mathrm{mg} \mathrm{m}^{-2}\right)$ and an additional 10 patients were treated at this dose level.

In the second step, $100 \mathrm{mg} \mathrm{m}^{-2}$ docetaxel was evaluated with 30 and $35 \mathrm{mg} \mathrm{m}^{-2}$ ombrabulin. One patient with $30 \mathrm{mg} \mathrm{m}^{-2}$ ombrabulin had grade 4 febrile neutropaenia 1 week after the docetaxel infusion, despite receiving prophylactic G-CSF. At $35 \mathrm{mg} \mathrm{m}^{-2}$ ombrabulin, DLTs were reported in two patients, one with grade 3 fatigue (2 days post-docetaxel) and one with grade 3 deep vein thrombosis (2 weeks postdocetaxel). The RP2D was set
Table 1. Patient and disease characteristics

\begin{tabular}{|l|l|}
\hline$N$ patients treated & 58 \\
\hline Female, $N(\%)$ & $35(60 \%)$ \\
Age in years, median (range) & $53(28-71)$ \\
Caucasian, $N(\%)$ & $54(93 \%)$ \\
\hline
\end{tabular}

ECOG performance status, $N(\%)$

\begin{tabular}{l|l}
$0 / 1$ & $28(48 \%) / 30(52 \%)$
\end{tabular}

Primary tumour site, $N(\%)$

\begin{tabular}{|l|c}
\hline Breast & $21(36 \%)$ \\
Oesophagus & $14(24 \%)$ \\
Muscle/soft tissue & $5(9 \%)$ \\
Pancreas & $5(9 \%)$ \\
Prostate & $3(5 \%)$ \\
Other $^{a}$ & $10(17 \%)$ \\
Metastatic disease, N (\%) & $52(90 \%)$
\end{tabular}

Prior therapy, $N(\%)$

\begin{tabular}{|l|l}
\hline Chemotherapy $^{\mathbf{b}}$ & $49(84 \%)$
\end{tabular}

\begin{tabular}{l|l} 
Surgery & $39(67 \%)$
\end{tabular}

Radiotherapy $\quad 31(53 \%)$

\begin{tabular}{l|l} 
Hormone & $19(33 \%)$
\end{tabular}

Biologics

$6(10 \%)$

Abbreviation: $\mathrm{ECOG}=$ Eastern Cooperative Oncology Group.

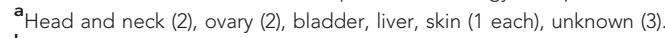

b Includes 33 patients (57\%) with prior taxane therapy.

at $30 \mathrm{mg} \mathrm{m}^{-2}$ ombrabulin with $100 \mathrm{mg} \mathrm{m}^{-2}$ docetaxel (30/ $100 \mathrm{mg} \mathrm{m}^{-2}$ ) and an additional 10 patients were enrolled at this dose level.

Haematological toxicity. Grade 1-2 haematological toxicity was common (Table 3) however anaemia was prevalent prior to treatment (28\% of patients). Grade 3-4 neutropaenia and leukopaenia were reported at all dose levels, including 36\% and $21 \%$ of patients treated with $75 \mathrm{mg} \mathrm{m}^{-2}$ docetaxel, respectively, and $58 \%$ and $53 \%$ of patients, respectively, at $100 \mathrm{mg} \mathrm{m}^{-2}$. No grade 3-4 thrombocytopaenia was reported. Prophylactic use of G-CSF was permitted. During the first cycle, prophylactic G-CSF was administered in 30 patients treated with $75 \mathrm{mg} \mathrm{m}^{-2}$ docetaxel (77\%) and 18 patients (95\%) at $100 \mathrm{mg} \mathrm{m}^{-2}$ docetaxel. Overall G-CSF was administered in 32 (82\%) and 19 (100\%) patients, respectively.

Non-haematological toxicity. Related non-haematological AEs were mainly grade $1-2$ (Table 4). At $75 \mathrm{mg} \mathrm{m}^{-2}$ docetaxel, the most common AEs were asthaenia/fatigue (69\%), nausea (64\%), alopecia (56\%), and vomiting (31\%). Incidences were similar at $100 \mathrm{mg} \mathrm{m}^{-2}$ docetaxel with the exception of asthaenia/fatigue which was more frequent (95\%). Additional toxicities at $100 \mathrm{mg} \mathrm{m}^{-2}$ docetaxel included diarrhoea (68\%), peripheral sensory neuropathy/peripheral neuropathy (58\%), nail disorders (58\%), dysgeusia/ageusia (58\%), and peripheral oedema (42\%). Other cutaneous reactions were reported in $10 \%$ to $15 \%$ of patients including hand/foot syndrome, erythema, and pruritus. Grade 1-2 hepatic enzyme elevations were common at all dose levels, however baseline elevations in ALT and alkaline phosphatase were present in $31 \%$ and $36 \%$ of patients, respectively.

Grade 3-4 non-haematological toxicities were reported in only one patient each with the exception of alkaline phosphatase elevations (four patients), fatigue (three patients), thrombosis, and AST/ALT elevations (two patients each). One patient (15.5/ $75 \mathrm{mg} \mathrm{m}^{-2}$ ) had unrelated acute renal failure with grade 4 
Table 2. Treatment exposure and DLT

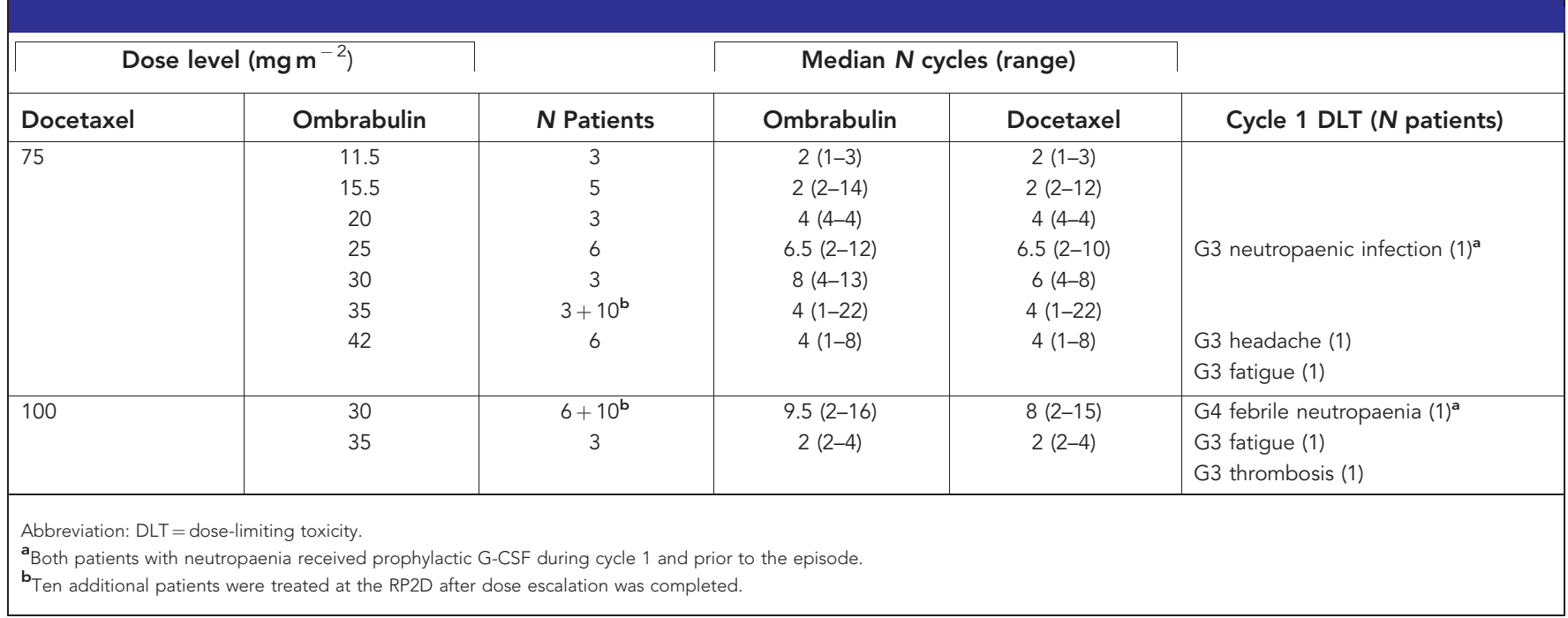

Table 3. Haematological toxicity (NCl-CTCAE)

\begin{tabular}{|c|c|c|c|c|}
\hline & \multicolumn{4}{|c|}{$N$ patients (\%) } \\
\hline & \multicolumn{2}{|c|}{$\begin{array}{l}11.5-42 \mathrm{mg} \mathrm{m}^{-2} \\
\text { ombrabulin/ } \\
75 \mathrm{mg} \mathrm{m}^{-2} \\
\text { docetaxel }(\mathrm{N}=39)\end{array}$} & \multicolumn{2}{|c|}{$\begin{array}{l}30-35 \mathrm{mg} \mathrm{m}^{-2} \\
\text { ombrabulin/ } \\
100 \mathrm{mg} \mathrm{m}^{-2} \\
\text { docetaxel }(N=19)\end{array}$} \\
\hline & All grades & G3-4 & All grades & G3-4 \\
\hline Leukopaenia & $22(56 \%)$ & $8(21 \%)$ & 15 (79\%) & 10 (53\%) \\
\hline Neutropaenia $^{a}$ & $18(46 \%)$ & $14(36 \%)$ & 13 (68\%) & $11(58 \%)$ \\
\hline Lymphopaenia & 30 (77\%) & $8(21 \%)$ & 15 (79\%) & $7(37 \%)$ \\
\hline Anaemia & $39(100 \%)$ & $1(3 \%)$ & 18 (95\%) & - \\
\hline Thrombocytopaenia & $14(36 \%)$ & - & 9 (47\%) & - \\
\hline \multicolumn{5}{|c|}{$\begin{array}{l}\text { Abbreviation: NCI-CTCAE }=\text { National Cancer Institute Common Toxicity Criteria for Adverse } \\
\text { Events. } \\
\text { a Note that prophylactic G-CSF was administered at least once to } 32 \text { patients treated at } \\
75 \mathrm{mg} \mathrm{m}^{-2} \text { docetaxel and all } 19 \text { patients treated at } 100 \mathrm{mg} \mathrm{m}^{-2} \text { docetaxel. }\end{array}$} \\
\hline
\end{tabular}

creatinine elevation and hypernatraemia which recovered with treatment. Related grade 4 sepsis occurred in one patient (20/ $75 \mathrm{mg} \mathrm{m}^{-2}$ ) which did not resolve despite treatment discontinuation, developing to febrile neutropaenia and grade 3 respiratory failure resulting in death. Two other patients $\left(35 / 75 \mathrm{mg} \mathrm{m}^{-2}\right)$ discontinued due to related events (grade 3 thrombosis and grade 2 gastrointestinal fistula). Ombrabulin dose reductions were reported in four patients (at the two highest ombrabulin levels) following grade 3 ALT, headache, or thrombosis. Docetaxel dose reductions were implemented in 18 patients $(31 \%)$, most at $30 / 100 \mathrm{mg} \mathrm{m}^{-2}$ (9 of 16 patients), and were generally due to mild to moderate oedema, fatigue/asthaenia, or skin/nail disorders. Of the 348 cycles administered, 8 were delayed and 10 were temporarily interrupted due to ombrabulin toxicity, whereas 27 docetaxel cycles were interrupted due to toxicity.

Related cardiovascular events were reported in nine patients (16\%), mostly at $30 \mathrm{mg} \mathrm{m}^{-2}$ ombrabulin or higher. Tachycardia (atrial, sinus, or supraventricular) was reported in five patients, palpitations in three patients, and AV block and sinus arrhythmia in one patient each. Vascular events occurred in 22 patients (38\%) including phlebitis in five patients at a range of dose levels, thrombosis in two and hypotension, flushing and haematoma in one patient each. All related cardiovascular events were grade 1-2 with the exception of thrombosis (two grade 3 episodes). One
Table 4. Non-haematological drug-related AEs, in $>20 \%$ patients or grade 3-4 (NCl-CTCAE)

\begin{tabular}{|c|c|c|c|c|}
\hline & \multicolumn{4}{|c|}{$N$ patients (\%) } \\
\hline & \multicolumn{2}{|c|}{$\begin{array}{l}11.5-42 \mathrm{mg} \mathrm{m}^{-2} \\
\text { ombrabulin/ } \\
75 \mathrm{mg} \mathrm{m}^{-2} \\
\text { docetaxel }(\mathrm{N}=39)\end{array}$} & \multicolumn{2}{|c|}{$\begin{array}{l}30-35 \mathrm{mg} \mathrm{m}^{-2} \\
\text { ombrabulin/ } \\
100 \mathrm{mg} \mathrm{m}^{-2} \\
\text { docetaxel }(\mathrm{N}=19)\end{array}$} \\
\hline & All grades & G3-4 & All grades & G3-4 \\
\hline Nausea & 25 (64\%) & - & $11(58 \%)$ & - \\
\hline Alopecia & $22(56 \%)$ & - & 13 (68\%) & - \\
\hline Fatigue & 15 (38\%) & $2(5 \%)$ & $8(42 \%)$ & $1(5 \%)$ \\
\hline Asthaenia & 12 (31\%) & - & $10(53 \%)$ & - \\
\hline Vomiting & $12(31 \%)$ & - & 7 (37\%) & - \\
\hline Decreased appetite & $10(26 \%)$ & $1(3 \%)$ & 7 (37\%) & - \\
\hline Diarrhoea & 9 (23\%) & - & $13(68 \%)$ & - \\
\hline Dysgeusia & $9(23 \%)$ & - & $4(21 \%)$ & - \\
\hline $\begin{array}{l}\text { Peripheral sensory } \\
\text { neuropathy }{ }^{a}\end{array}$ & $3(8 \%)$ & - & $9(47 \%)$ & - \\
\hline Myalgia & $6(15 \%)$ & - & $7(37 \%)$ & - \\
\hline Stomatitis & $5(13 \%)$ & - & $5(26 \%)$ & - \\
\hline Oedema (peripheral) & $4(10 \%)$ & - & $8(42 \%)$ & - \\
\hline Headache & $3(8 \%)$ & $1(3 \%)$ & 4 (21\%) & - \\
\hline Nail disorder & $3(8 \%)$ & - & $11(58 \%)$ & - \\
\hline Ageusia & $3(8 \%)$ & - & $9(47 \%)$ & - \\
\hline Increased lacrimation & $2(5 \%)$ & - & $7(37 \%)$ & - \\
\hline Arthralgia & $1(3 \%)$ & - & $4(21 \%)$ & $1(5 \%)$ \\
\hline Thrombosis & $1(3 \%)$ & $1(3 \%)$ & $1(5 \%)$ & $1(5 \%)$ \\
\hline Febrile neutropaenia & - & - & $1(5 \%)$ & $1(5 \%)$ \\
\hline Hand/foot syndrome & $2(5 \%)$ & - & $3(16 \%)$ & $1(5 \%)$ \\
\hline Neutropaenic infection & $2(5 \%)$ & $1(3 \%)$ & $1(5 \%)$ & - \\
\hline Oesophageal fistula & $1(3 \%)$ & $1(3 \%)$ & - & - \\
\hline Nail toxicity & $2(5 \%)$ & $1(3 \%)$ & - & - \\
\hline Sepsis & $1(3 \%)$ & $1(3 \%)$ & - & - \\
\hline Respiratory failure & $1(3 \%)$ & $1(3 \%)$ & - & - \\
\hline \multicolumn{5}{|c|}{$\begin{array}{l}\text { Abbreviations: } A E=\text { adverse event; } N C I-C T C A E=\text { National Cancer Institute Common } \\
\text { Toxicity Criteria for Adverse Events. } \\
\text { a Peripheral neuropathy was reported in an additional } 5(13 \%) \text { patients at } 75 \mathrm{mg} \mathrm{m}^{-2} \text { and } 3 \\
(16 \%) \text { at } 100 \mathrm{mg} \mathrm{m}^{-2} \text {. }\end{array}$} \\
\hline
\end{tabular}

patient had a minimal LVEF decrease (47\% compared with the lower limit of 50\%) and CK-MB elevations were noted in two patients without concomitant cardiovascular events. A single case 
of unrelated and transient grade 3 hypertension was observed. BP abnormalities were reported in eight patients, most of which were transient. A retrospective expert cardiologic evaluation confirmed these results.

Anti-tumour activity. All patients were evaluated for response according to RECIST 1.0 (Table 5). Ten patients (17\%) had partial responses (PRs), seven with breast cancer, and one each with prostate, ovarian or oesophageal carcinoma. Seven of the responders were treated at $30 / 100 \mathrm{mg} \mathrm{m}^{-2}$ and all had a previous best response of SD or disease progression. Seven of the 33 patients who had previously received taxanes had PR with the ombrabulin/

\begin{tabular}{|c|c|c|c|}
\hline & $\begin{array}{c}75 \mathrm{mg} \mathrm{m}^{-2} \\
\text { docetaxel } \\
(N=39)\end{array}$ & $\begin{array}{c}100 \mathrm{mg} \mathrm{m}^{-2} \\
\text { docetaxel } \\
(N=19)\end{array}$ & $\begin{array}{c}\text { All } \\
(N=58)\end{array}$ \\
\hline \multicolumn{4}{|c|}{ Best overall response } \\
\hline PR & $3(7.7 \%)$ & $7(36.8 \%)$ & $10(17.2 \%)$ \\
\hline Stable disease & $18(46.2 \%)$ & 9 (47.4\%) & $27(46.6 \%)$ \\
\hline Disease progression & $17(43.6 \%)$ & $3(15.8 \%)$ & 20 (34.5\%) \\
\hline Not evaluable & $1(2.6 \%)$ & 0 & $1(1.7 \%)$ \\
\hline
\end{tabular}

Abbreviations: $\mathrm{PR}=$ partial response; $\mathrm{RECIST}=$ Response Evaluation Criteria in Solid Tumours.
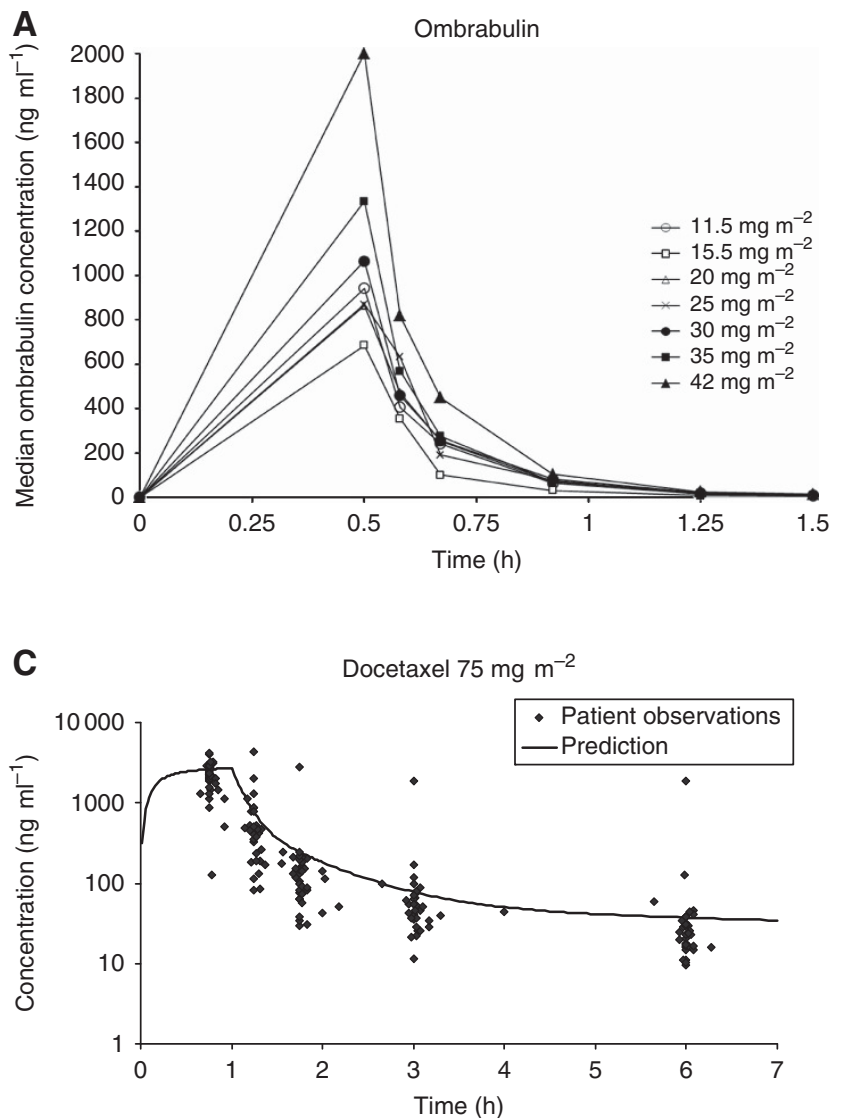

docetaxel doublet (two had a previous best response of PR and one had SD under docetaxel, and four were treated in the adjuvant setting). Eight PRs lasted for more than 3 months (range 2.7-8.5) with a median duration of 5.3 months. Stable disease was reported in 27 patients $(47 \%)$ at a range of dose levels, with a median duration of 4.6 months. The rate of disease control $(\mathrm{PR}+\mathrm{SD})$ was $81 \%$ in breast cancer patients (17 out of 21 ), $64 \%$ in oesophageal cancer patients ( 9 out of 14 ) and $100 \%$ in the three prostate cancer patients.

Pharmacokinetics. The pharmacokinetics of ombrabulin and its active metabolite RPR258063 were evaluated in 57 patients and pharmacokinetics of docetaxel were evaluated in 56 patients. A summary of results is provided in Table 6 and concentration time profiles of ombrabulin, its active metabolite RPR258063 and docetaxel are shown in Figure 1. Exposure to ombrabulin and RPR258063 was dose proportional with mean AUC ranging from $290 \mathrm{ng}^{\star} \mathrm{h} \mathrm{ml} l^{-1}$ to $856 \mathrm{ng}^{\star} \mathrm{h} \mathrm{ml}^{-1}$ and from $394 \mathrm{ng}^{\star} \mathrm{h} \mathrm{ml}{ }^{-1}$ to $1830 \mathrm{ng}^{\star} \mathrm{h} \mathrm{ml}^{-1}$, respectively. For ombrabulin, elimination was biphasic with rapid conversion to RPR258063 (mean half-life $12 \mathrm{~min}$ ) and high clearance of $67 \mathrm{lh}^{-1} \mathrm{~m}^{-2}$, whereas steady state volume of distribution was low at $30 \mathrm{~lm}^{-2}$. For RPR258063, a biphasic or triphasic elimination profile was observed with a terminal half-life of $8 \mathrm{~h}$. For docetaxel, mean clearance was $25.2 \pm 8.1$ and $23.2 \pm 5.0 \mathrm{lh}^{-1} \mathrm{~m}^{-2}$ after 75 and $100 \mathrm{mg} \mathrm{m}^{-2}$, respectively, corresponding to AUCs of $5.12 \pm 12.4 \mu \mathrm{g}^{\star} \mathrm{h} \mathrm{ml}{ }^{-1}$ and $4.59 \pm 1.38 \mu \mathrm{g}^{\star} \mathrm{h} \mathrm{ml}^{-1}$. One patient receiving $75 \mathrm{mg} \mathrm{m}^{-2}$ docetaxel had a very high AUC $\left(79.4 \mu \mathrm{g}^{\star} \mathrm{h} \mathrm{ml}^{-1}\right)$. When this value was excluded, mean AUC was $3.11 \pm 0.84 \mu \mathrm{g}^{\star} \mathrm{h} \mathrm{ml}^{-1}$.
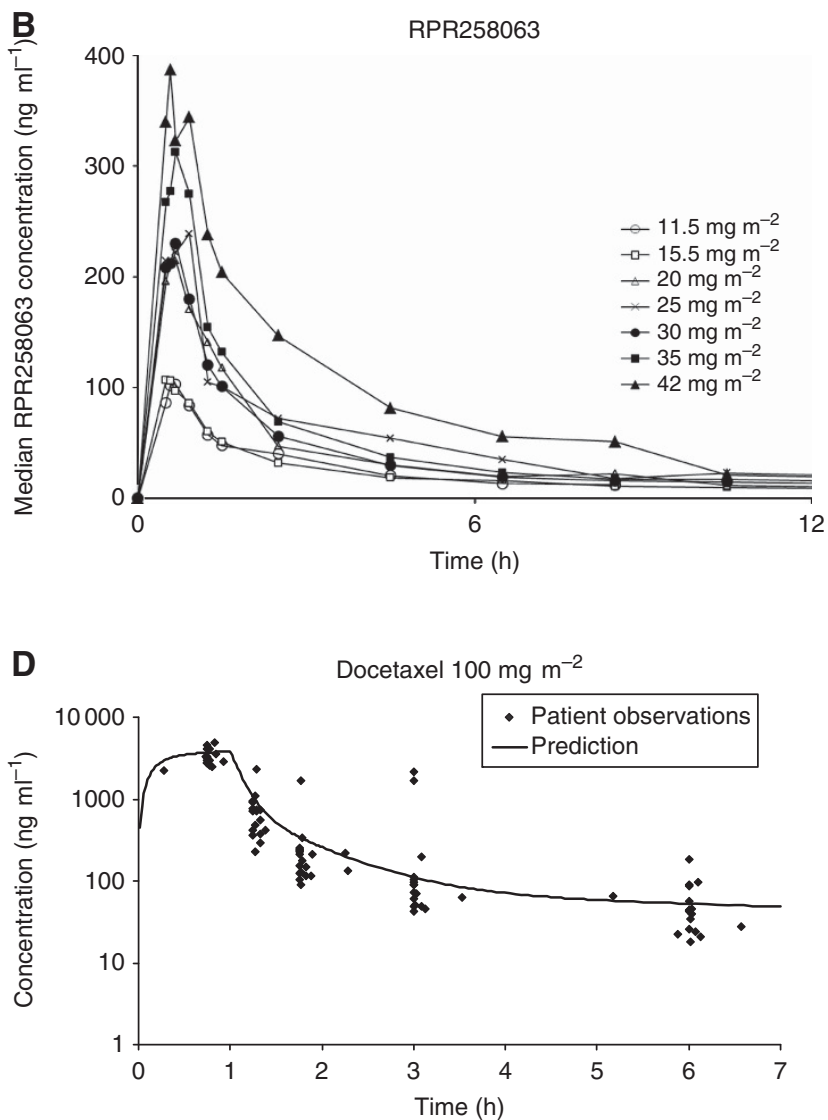

Figure 1. Concentration-time profiles of ombrabulin, its active metabolite RPR258063 and docetaxel. Plasma concentrations in cycle 1 are shown for (A) ombrabulin and (B) RPR258063 by dose level according to median concentrations $(N=57)$, and for docetaxel $(C) 75 \mathrm{mg} \mathrm{m}^{-2}(\mathrm{~N}=38)$ and (D) $100 \mathrm{mg} \mathrm{m}^{-2}(\mathrm{~N}=18)$ presenting individual results against predicted values for a patient with a body surface area of $1.76 \mathrm{~m}^{2}$ and $1.89 \mathrm{~m}^{2}$, respectively. 


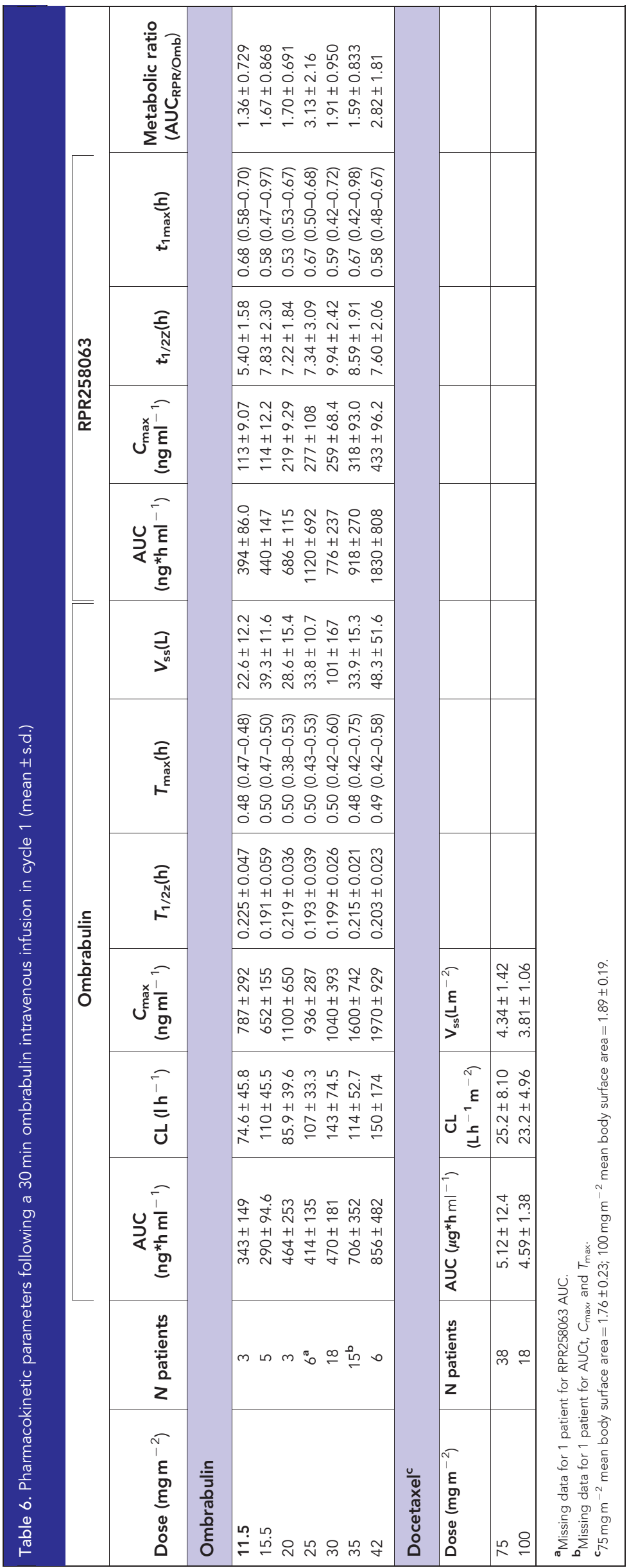




\section{DISCUSSION}

The current study demonstrates the feasibility of integrating ombrabulin into two standard docetaxel regimens of 75 and $100 \mathrm{mg} \mathrm{m}^{-2}$, which are approved for use in a variety of clinical settings in different tumour types. Three DLTs were reported with each docetaxel dose. Neutropaenic complications were dose-limiting at lower ombrabulin doses $\left(25\right.$ and $30 \mathrm{mg} \mathrm{m}^{-2}$ ) with both docetaxel doses, while headache, fatigue, and thrombosis were dose-limiting at 35 and $42 \mathrm{mg} \mathrm{m}^{-2}$ ombrabulin with both docetaxel doses. The recommended combination doses for further clinical studies were therefore set at $35 \mathrm{mg} \mathrm{m}^{-2}$ ombrabulin/ $75 \mathrm{mg} \mathrm{m}^{-2}$ docetaxel and $30 \mathrm{mg} \mathrm{m}^{-2}$ ombrabulin/100 $\mathrm{mg} \mathrm{m}^{-2}$ docetaxel.

The DLTs reported are consistent with the single-agent profiles. Neutropaenic complications are associated with docetaxel, but were not reported with single-agent ombrabulin (Sessa et al, 2013). Headache and fatigue were frequent with ombrabulin, and grade 3 thrombosis occurred at the highest ombrabulin single-agent dose evaluated $\left(50 \mathrm{mg} \mathrm{m}^{-2}\right)$, although none of these toxicities were dose-limiting with ombrabulin monotherapy. The addition of ombrabulin to docetaxel at doses commonly used in standard therapeutic regimens did not compromise the safety of either agent, and there was no indication of prolonged or cumulative toxicities. As expected, prominent toxicities associated with docetaxel were dose-dependent grade 3-4 neutropaenia and leukopaenia. Common grade 1-2 non-haematological toxicities such as asthaenia, nausea, vomiting, diarrhoea, and neuropathy are coherent with the toxicity profiles of both docetaxel (75 and $100 \mathrm{mg} \mathrm{m}^{-2}$ ) and ombrabulin (Sessa et al, 2013), as was the higher frequency of diarrhoea, nail disorders, oedema, and neuropathy with $100 \mathrm{mg} \mathrm{m}^{-2}$ docetaxel compared with $75 \mathrm{mg} \mathrm{m}^{-2}$ (Extra et al, 1993; Harvey et al, 2006). Other ombrabulin-related toxicities such as headache and abdominal pain were reported but were only mild (grade 1-2). Notably, tumour pain which is considered to be VDA dose-dependent was rarely reported at the two ombrabulin combination RP2Ds (30 and $35 \mathrm{mg} \mathrm{m}^{-2}$ ). Overlapping toxicities for the two agents, notably asthaenia, digestive toxicities, abdominal pain, and neuropathy, rarely required dose reductions or delays.

An expert cardiovascular review concluded that with the absence of ischemic episodes, cardiac decompensation, ECG, and cardiac biomarker abnormalities, and no cases of related hypertension notably in the ten patients with a history of hypertension, the addition of ombrabulin to docetaxel at the proposed RP2Ds does not impose cardiovascular restrictions. This supports previous reports that cardiovascular toxicity does not present a limitation to ombrabulin use (Soria et al, 2008; Sessa et al, 2013). Nonetheless, and given the as yet limited clinical experience with ombrabulin, appropriate screening and close cardiovascular surveillance during treatment remain a recommended aspect of ombrabulin use.

It has been suggested that the strategy of combining a chemotherapeutic agent with a VDA may prevent development of a rim of viable tumour cells surrounding the necrotic core which is characteristic of advanced solid tumours (Tozer et al, 2005). This not only targets the proliferating border of tumours, but also offers a potential means of overcoming drug resistance which can impose limitations on the use of cytotoxic agents. Although intriguing preclinical evidence has urged exploration of this sequence in a clinical setting, the exact molecular explanation for how ombrabulin and docetaxel interact has not been fully elucidated. In a recent review (McKeage and Baguley, 2010), it was suggested that VDAs are able to access poorly perfused regions which are inaccessible to chemotherapy molecules (Siim et al, 2003). Another possibility is that VDAs result in decreased tumoural clearance of chemotherapy agents and increased tumoural susceptibility to chemotherapeutic agents via micro-environmental changes (Pruijn et al, 1997).

Pharmacokinetic analyses of ombrabulin over the $24 \mathrm{~h}$ following its administration showed dose proportionality and rapid conversion to its metabolite RPR258063. As expected with this analysis performed prior to docetaxel administration, the outcome was similar to that reported in the monotherapy study (Sessa et al, 2013), although volume of distribution and clearance were higher than with monotherapy. Docetaxel parameters following ombrabulin administration were also consistent with published singleagent data (Bruno et al, 1998; Harvey et al, 2006). Systemic exposure of docetaxel thus does not appear to be altered by preceding administration of ombrabulin $24 \mathrm{~h}$ earlier, confirming the absence of relevant drug interaction when administered according to this schedule.

Responses and durable SD were seen across all dose levels. Several PRs were reported in breast cancer patients, which is coherent with reported response rates ranging from 23\% to $48 \%$ with single-agent docetaxel in metastatic breast cancer patients (Bonneterre et al, 1999; Chan et al, 1999; Nabholtz et al, 1999; Sjostrom et al, 1999; Bonneterre et al, 2002; Jones et al, 2005). Activity in oesophageal cancer patients was encouraging and although only three prostate cancer patients were included, all had clinical benefit suggesting further investigation in these indications may be worthwhile.

Evaluation of biomarkers indicative of sensitivity to tubulininteracting agents, tumour vascularisation or angiogenesis and endothelial cells is an important step in the clinical development of ombrabulin in order to establish a predictive signature, with the ratio of mature to immature vessel markers potentially correlating with response outcome. An exploratory analysis performed as part of this study, unfortunately, did not show clear correlations between biomarker expression in archived tissue and outcome. It has to be emphasised that our analysis was hampered by the small sample size and very few on-study evaluations and further investigation of these parameters therefore is needed.

This study has determined the ombrabulin recommended doses for further clinical development in combination with two docetaxel doses that are frequently used in standard 3-weekly schedules. In an extension of this regimen, the addition of ombrabulin to platinum/taxane doublets has meanwhile been evaluated in a phase II study in non-small cell lung cancer patients (von Pawel et al, 2012). Further studies to assess the added value of ombrabulin to other cytotoxic regimens will be undertaken.

\section{ACKNOWLEDGEMENTS}

We thank Patricia Fernandez (Sanofi, France) for study management support, Eric Le Bras (Sanofi, France) for programming support, and Sarah MacKenzie (Medi.Axe, France, funded by Sanofi) for assistance drafting the manuscript. The study was funded by Sanofi and the institutes of FAE and VD received grant support from Sanofi for this clinical trial.

\section{CONFLICT OF INTEREST}

HF, CVF, CO, and MH are employees of Sanofi. FAE and VD received institutional financial support for this study from Sanofi. All other authors have no conflict of interest.

\section{REFERENCES}

Bonneterre J, Roche H, Monnier A, Guastalla JP, Namer M, Fargeot P, Assadourian S (2002) Docetaxel vs 5-fluorouracil plus vinorelbine in 
metastatic breast cancer after anthracycline therapy failure. $\mathrm{Br} J$ Cancer 87: 1210-1215.

Bonneterre J, Spielman M, Guastalla JP, Marty M, Viens P, Chollet P, Roche H, Fumoleau P, Mauriac L, Bourgeois H, Namer M, Bergerat JP, Misset JL, Trandafir L, Mahjoubi M (1999) Efficacy and safety of docetaxel (Taxotere) in heavily pretreated advanced breast cancer patients: the French compassionate use programme experience. Eur J Cancer 35: 1431-1439.

Bruno R, Hille D, Riva A, Vivier N, ten Bokkel Huinnink WW, van Oosterom AT, Kaye SB, Verweij J, Fossella FV, Valero V, Rigas JR, Seidman AD, Chevallier B, Fumoleau P, Burris HA, Ravdin PM, Sheiner LB (1998) Population pharmacokinetics/pharmacodynamics of docetaxel in phase II studies in patients with cancer. J Clin Oncol 16: 187-196.

Bruno R, Vivier N, Vergniol JC, De Phillips SL, Montay G, Sheiner LB (1996) A population pharmacokinetic model for docetaxel (Taxotere): model building and validation. J Pharmacokinet Biopharm 24: 153-172.

Chan S, Friedrichs K, Noel D, Pinter T, Van Belle S, Vorobiof D, Duarte R, Gil Gil M, Bodrogi I, Murray E, Yelle L, von Minckwitz G, Korec S, Simmonds P, Buzzi F, Gonzalez Mancha R, Richardson G, Walpole E, Ronzoni M, Murawsky M, Alakl M, Riva A, Crown J (1999) Prospective randomized trial of docetaxel versus doxorubicin in patients with metastatic breast cancer. J Clin Oncol 17: 2341-2354.

Del Conte G, Bahleda R, Moreno V, Damian S, Perotti A, Lassau N, Farace F, Ong M, Stimpson S, Tunariu T, Micallef S, Demers B, Oprea C, Capri G, Soria J, Sessa C, Molife R (2012) A phase I study of ombrabulin (O) combined with bevacizumab (B) in patients with advanced solid tumors (NCT01193595) [Abstract]. J Clin Oncol 30(Suppl): Abstr No. 3080.

Extra JM, Rousseau F, Bruno R, Clavel M, Le Bail N, Marty M (1993) Phase I and pharmacokinetic study of Taxotere (RP 56976; NSC 628503) given as a short intravenous infusion. Cancer Res 53: 1037-1042.

Harvey V, Mouridsen H, Semiglazov V, Jakobsen E, Voznyi E, Robinson BA, Groult V, Murawsky M, Cold S (2006) Phase III trial comparing three doses of docetaxel for second-line treatment of advanced breast cancer. J Clin Oncol 24: 4963-4970.

Hori K, Saito S (2003) Microvascular mechanisms by which the combretastatin A-4 derivative AC7700 (AVE8062) induces tumour blood flow stasis. Br J Cancer 89: 1334-1344.

Jones SE, Erban J, Overmoyer B, Budd GT, Hutchins L, Lower E, Laufman L, Sundaram S, Urba WJ, Pritchard KI, Mennel R, Richards D, Olsen S, Meyers ML, Ravdin PM (2005) Randomized phase III study of docetaxel compared with paclitaxel in metastatic breast cancer. J Clin Oncol 23: $5542-5551$.

Kanthou C, Tozer GM (2002) The tumor vascular targeting agent combretastatin A-4-phosphate induces reorganization of the actin cytoskeleton and early membrane blebbing in human endothelial cells. Blood 99: 2060-2069.

Kim TJ, Ravoori M, Landen CN, Kamat AA, Han LY, Lu C, Lin YG, Merritt WM, Jennings N, Spannuth WA, Langley R, Gershenson DM, Coleman RL, Kundra V, Sood AK (2007) Antitumor and antivascular effects of AVE8062 in ovarian carcinoma. Cancer Res 67: 9337-9345.

Lejeune P, Vrignaud P, Goulaouic H, Nicolas S, Bissery M-C (2005) In vivo synergy between docetaxel and AVE8062A, a tumor vasculature targeting agent [Abstract]. Proc AACR Annual Meeting 46: Abstr No. 3425.

McKeage MJ, Baguley BC (2010) Disrupting established tumor blood vessels: an emerging therapeutic strategy for cancer. Cancer 116: 1859-1871.

Nabholtz JM, Senn HJ, Bezwoda WR, Melnychuk D, Deschenes L, Douma J, Vandenberg TA, Rapoport B, Rosso R, Trillet-Lenoir V, Drbal J,
Molino A, Nortier JW, Richel DJ, Nagykalnai T, Siedlecki P, Wilking N, Genot JY, Hupperets PS, Pannuti F, Skarlos D, Tomiak EM, Murawsky M, Alakl M, Aapro M et al. (1999) Prospective randomized trial of docetaxel versus mitomycin plus vinblastine in patients with metastatic breast cancer progressing despite previous anthracycline-containing chemotherapy. 304 Study Group. J Clin Oncol 17: 1413-1424.

Nathan P, Zweifel M, Padhani AR, Koh DM, Ng M, Collins DJ, Harris A, Carden C, Smythe J, Fisher N, Taylor NJ, Stirling JJ, Lu SP, Leach MO, Rustin GJ, Judson I (2012) Phase I trial of combretastatin A4 phosphate (CA4P) in combination with bevacizumab in patients with advanced cancer. Clin Cancer Res 18: 3428-3439.

Pruijn FB, van Daalen M, Holford NH, Wilson WR (1997) Mechanisms of enhancement of the antitumour activity of melphalan by the tumourblood-flow inhibitor 5,6-dimethylxanthenone-4-acetic acid. Cancer Chemother Pharmacol 39: 541-546.

Sessa C, Lorusso P, Tolcher A, Farace F, Lassau N, del Monte A, Braghetti A, Bahleda R, Cohen P, Hospitel M, Veyrat-Follet C, Soria JC (2013) Phase 1 safety, pharmacokinetic and pharmacodynamic evaluation of the vascular disrupting agent ombrabulin (AVE8062) in patients with advanced solid tumors. Clin Cancer Res 19: 4832-4842.

Siim BG, Lee AE, Shalal-Zwain S, Pruijn FB, McKeage MJ, Wilson WR (2003) Marked potentiation of the antitumour activity of chemotherapeutic drugs by the antivascular agent 5,6-dimethylxanthenone-4-acetic acid (DMXAA). Cancer Chemother Pharmacol 51: 43-52.

Sjostrom J, Blomqvist C, Mouridsen H, Pluzanska A, Ottosson-Lonn S, Bengtsson NO, Ostenstad B, Mjaaland I, Palm-Sjovall M, Wist E, Valvere V, Anderson H, Bergh J (1999) Docetaxel compared with sequential methotrexate and 5-fluorouracil in patients with advanced breast cancer after anthracycline failure: a randomised phase III study with crossover on progression by the Scandinavian Breast Group. Eur J Cancer 35: 1194-1201.

Soria J, Sessa C, Perotti A, Massard C, JP A, Lassau N, Farace F, Elsa B, Gianni L (2008) A comprehensive study of translational research and safety exploration of the vascular disrupting agent (VDA) AVE8062 in combination with cisplatin administered every 3 weeks to patients with advanced solid tumors [Abstract]. Proc AACR Annual Meeting 49: Abstr LB-302.

Therasse P, Arbuck SG, Eisenhauer EA, Wanders J, Kaplan RS, Rubinstein L, Verweij J, Van Glabbeke M, van Oosterom AT, Christian MC, Gwyther SG (2000) New guidelines to evaluate the response to treatment in solid tumors. European Organization for Research and Treatment of Cancer, National Cancer Institute of the United States, National Cancer Institute of Canada. J Natl Cancer Inst 92: 205-216.

Tozer GM, Kanthou C, Baguley BC (2005) Disrupting tumour blood vessels. Nat Rev Cancer 5: 423-435.

von Pawel J, Gorbomunova V, Reck M, Kowalski D, Allard A, Chadjaa M, Rey A, Bennouna J, Grossi F (2012) DISRUPT: a randomized phase 2 trial of ombrabulin (AVE8062) combined with a taxane-platinum regimen in the first-line treatment of metastatic non-small cell lung cancer (NSCLC) [Abstract]. Ann Oncol 23 (SupplAbs. 1250P.

This work is published under the standard license to publish agreement. After 12 months the work will become freely available and the license terms will switch to a Creative Commons AttributionNonCommercial-Share Alike 3.0 Unported License. 